\title{
IMAGE-CREATING FUNCTION AND CREATION OF RELIABLE AND ACCURATE INFORMATION IN THE ACCOUNTING SYSTEM
}

\author{
Artur Jastrzębowski ${ }^{1}$ \\ Marek Wierzbiński \\ Zofia Wierzbińska ${ }^{3}$
}

DOI: https://doi.org/10.31410/ERAZ.2019.277

\begin{abstract}
The purpose of this article was to present the impact of the accounting's image-creating function on the quality of information generated by the accounting system. Accounting has increased the range of functions over the years. Nowadays, in literature, there are many functions realized by accounting, including, among others, the image-creating function. For the wide range of recipients of information coming from the accounting system, its quality (understood through the prism of usefulness and usability) is very important. The desire to realize the image-accounting function may lead to the distortion of financial information. Therefore, it is especially necessary to supervise the observance of the principles of a faithful and reliable image.
\end{abstract}

Keywords: image-creating function of accounting, information function of accounting, quality of information in the financial statements

\section{INTRODUCTION}

$\mathrm{T}$ he evolution of the accounting system has led to an increase in the catalogue of functions performed by this system. The currently distinguished functions realized by the accounting system include, among others, the image-creating function, the aim of which is (inter alia, to create the image of an individual among various groups of stakeholders, while maintaining the principle of a faithful and reliable image). At present, due to the wide catalogue of recipients of information from the accounting system, the quality of presented information, which determines the perception of an individual among various groups of stakeholders, has become an important aspect.

This article aims to present the accounting's image-creating function, which has been specified in the accounting system as a derivative of the information function and translate it into the quality of information presented in the financial statements. The content of the elaboration has been divided into three parts preceded by an introduction and summarized by the ending. The first part is aimed at introducing the accounting's image-creating function. Subsequently, there are consideration about the quality of information from the financial statements prepared in accordance with national or international regulations. The third part presents the relation between the image-creating function of accounting and the information quality of financial statements. The study is based on the method of critical analysis of the literature in the field of accounting theory.

1 University of Economics in Poznań, Department of Accountancy, al. Niepodleglosci 10, 61-875 Poznan, Poland

2 University of Economics in Poznań, Department of Controlling, Financial Analysis and Evaluation, al. Niepodleglosci 10, 61-875 Poznan, Poland

3 University of Economics in Poznań, Department of Accountancy, al. Niepodleglosci 10, 61-875 Poznan, Poland 


\section{THE IMAGE-CREATING FUNCTION OF ACCOUNTING AS A DERIVATIVE OF THE INFORMATION FUNCTION}

Contemporary accounting forms one of the basic information system of an enterprise. A wide set of users characterized by diverse expectations regarding the demand for data used in the decision-making process causes that the essence of accounting can be understood in a various way.

As it was noted by A. Szychta [1996, pp. 20-22], apart from the basic distinction between the discipline of science and practical activity, views on the empirical nature of accounting are also characterized by a large variation of its leading accents, which (in turn) results in the determination of accounting as:

- Information system,

- System for records of economic events,

- Language of business,

- Measurement system,

- Type of service activity,

- Reflection of real states and processes,

- Ideology.

Among the above-mentioned views, special attention should be paid to the position according to which the accounting system is an information system. Therefore, it performs actions, which are typical for systems - such as "input" (data), "processing" and "output" (information) [Nowak 1994, pp. 79-80]. As you can see, in this approach, information is an element that focuses attention. This causes that theorists define accounting as an information system, which identifies, records and informs stakeholders of an entity about economic events taking place in the unit [Smejda 2011, p. 105]. This definition may be extended, because, according to W. Brzezin [1998, p. 21], accounting is a complex information system (in this case - referred to as information-control system of a retrospective and prospective nature), adapted to the financial management of an enterprise.

Such a strong emphasis in literature on the identification of accounting with the information system results in a common view of the supremacy of the information function over other functions performed by accounting [Cieciura, 2016, p. 68].

According to the proposed definitions, this function can be understood as the creation of specific sets of information, their processing, and transfer to the management of the unit for the purpose of their adequate use in the management process [Messner 2003, pp. 27-28].

It was similarly described by K. Szymczyk-Madej [2007, p. 156]. She indicated that the information function is based on the creation of specific sets of information for the needs of business management, which are useful for external recipients.

It is worth nothing that according to H. Poetschke [2011, p. 16], the information system can be divided into:

- External information function,

- Internal information function. 
Currently, it is assumed that financial accounting constituting one of the accounting subsystems is responsible for providing information to external users. The purpose of the developed information is to present the assets and capital of the company and registration of factors shaping the entity's financial result. This information has retrospective nature and constitutes the main source of shaping the external image of the individual. Provision of information for external stakeholders takes places (mainly) through financial statements [Kurek and Zielińska 2000, pp. 145-146].

On the other hand, the internal information function is realized both by the financial accounting subsystem and the subsystem of management accounting. Information generated by financial accounting is not sufficient for the needs of making optimal economic decision by the management of an individual. Therefore, as it is emphasized by H. Kurek and H. Zielińska [2000, p. 147], the resulting gap is filled with management accounting, which is aimed at supporting the decision-making process. The information generated in the management accounting subsystem is informal nature and it is largely shaped by individual needs of the individual's management. The information is based on data expressed both in the money measure and natural units.

The above analyzes of the information function focus on the process of satisfying the needs of users in terms of specific data used in solving the decision-making process. However, the transmitted information also creates a specific picture of the individual. This process can be identified as the implementation of the image-creating function of accounting.

In accordance with the proposed definition [Jastrzębowski 2015, p. 171], the implementation of the image-creating function is connected with "undertaking activities involving the proper modification of the enterprise's accounting policy" (including, in particular, selection of methods for evaluation of assets and sources of financing for the unit, as well as recognition of its revenues and costs) in order to create an image of the unit consistent with the particular interests of the entity's management bodies, in front of external units in relation to the enterprise".

Activities taken as a part of the implementation of the image-creating function of accounting have a pro-active character, dependent on the will of people responsible for creating the system. This problem leads to the question of the quality of data obtained by users from the data accounting system, in the situation when the information function of accounting was applicable.

\section{QUALITY OF INFORMATION FROM THE ACCOUNTING SYSTEM ACCORDING TO NATIONAL AND INTERNATIONAL REGULATIONS}

According to the Accounting Act [Journal of Laws of 2018, item 395, as amended], entities are obliged to present their property and financial situation and financial result in a reliable and clear manner. Accounting principles such as the principle of accrual, matching and prudence are subordinated to this goal. Its implementation is carried out by legal acts constituting accounting frameworks, accounting policy of the unit, as well as institutionalized supervision over financial reporting of entities. In 2018, the position of the Accounting Standards Committee regarding the principle of reliable and clear image in the realization of the Accounting Act's provisions (intended to be another tool for achieving this goal) was prepared.

This position does not define what is meant by a reliable and clear image. However, it indicates the purpose of the financial statements, i.e. provision of useful (helpful and reliable) numerical and verbal information on the activities and situation of the unit [Position ..., point 5] for re- 
cipients. It determines legal acts regulating the minimum scope of information that should be presented by units to typical recipients. Moreover, it was found that due to the diverse subject of activity, size, legal form, etc. of units, it is not possible to cover all information needs with these acts. The solution of this inconvenience includes tools made available to unit managers enabling them to take into account these needs and circumstances, which are not specified in legal acts.

The fact that managers have the possibility of influencing the accounting policy and the shape of the financial report in order to implement the principle of a faithful and reliable image does not exclude the possibility of exerting influence also in other purposes, among others, in image-creating matters.

Credibility should be understood as reliability, truthfulness, certainty, responsibility, authenticity - credibility is a basic quality feature of useful information, determined by sources of information, and determining reliability and truthfulness of information [Zyznarska-Dworczak 2015, p. 192]. Reporting information is generated by the accounting system, and the fulfillment of certain quality features by this information enables to use it to reduce uncertainty in the decision-making process [Kaczmarczyk 2016, p. 126]. In relation to the above, it is so important that the reporting information is credible and reliable.

The concept of credibility is gradually taking over from the literature through a faithful image / reflection. This has its basis, among others, in amendments to the Conceptual Frameworks for IFRS and also in certain language inaccuracies arising in the process of translation of foreign legal acts and guidelines. The concept of faithful presentation is not the same as the concept of credibility. Changes towards faithful presentation are a consequence of the growing number of estimates introduced to the financial statements, making it impossible to ensure the full credibility. However, the aim of this article is to determine the impact of the image-creating function of accounting on the quality of information in general, and therefore - subtle features that differentiate both concepts will not affect further analysis.

Financial statements include financial and non-financial information. Lack of credibility and reliability in the first impulse are identified with the financial sphere. However, due to the growing interest in integrated reporting, as well as higher and higher requirements regarding the scope of non-financial information, the risk of the lack of credibility increases. This problem is highlighted by I. Matuszyk [2018, p. 108], who underlines the issues of potential selectivity of presented information, leading to the disclosure of information only beneficial from the marketing point of view, and concealing information unfavorable to the image of an individual.

A similar problem in the context of the credibility of the integrated statement is raised by K. Piotrowska [2016]. She narrows the considerations regarding the issue of sharing information about innovative activities with managers - in the context of the risk of weakening the competitive potential of the entity in the face of disclosure of such information.

Behaviors that reduce the credibility of information, such as selective presentation of data, may justify, among others, the occurrence of agency theory [cf. Rówińska 2016, pp. 520-521]. In view of the asymmetry in accessing information about the situation of the individual, where managers generating financial statements have a decisive advantage, the quality (i.e. credibility and reliability of the financial statements dedicated to the owners) may deteriorate as a result of adapting it to the realization of needs of managers in place of meeting the needs of the owners. 
First of all, the financial statements should be useful, i.e. they should enable to make decisions based on them. Credibility and reliability of information, next to suitability, should be considered as the premises for usability. Reliable, but unhelpful information will not be useful, just like useful-, but unreliable information. Although in some circumstances, there may be a conflict between the usefulness and reliability of reporting information [cf. Wierzbińska, 2012].

Therefore, for capital markets, it is very important to care for the credibility of data, because it is harder to assess the user's financial statements. The user is able to determine whether specific information is useful to him, because usefulness is a subjective feature - dependent, among others, on the needs and abilities of the user. On the other hand, verification of credibility requires information about the entity from other internal sources, which are not available to a typical user.

A tool to improve the reliability of reporting information is an audit of financial statements, obligatory for a selected group of entities. By analyzing the legal regulations of the audit [e.g. Act of statutory auditors, auditing companies and public supervision, Journal of Laws of 2017, item 1089, as amended], it can be noticed that there is an increased emphasis on the examination of reports of public interest entities. This group includes, among others, issuers of securities admitted to trading on regulated markets - i.e. entities, for whom image-creating issues related to the need to obtain capital are especially important.

\section{THE IMPACT OF THE IMAGE-CREATING FUNCTION ON THE QUALITY OF INFORMATION.}

Activities undertaken as a part of the implementation of the image-creating function of accounting have a pro-active nature, dependent on the will of people shaping the accounting system. Therefore, it is necessary to consider their impact on the achievement of credibility and reliability of information required by the theory of accounting.

As it was indicated in the previous point, legislative efforts in the field of balance sheet regulations strive to define a legal framework that enable to generate faithful and reliable information. Solutions can take one of two forms:

- Mandatory structures, realized in a clearly defined manner,

- Solutions with a selection field that enable to make autonomous decisions.

By referring to the pro-active nature of the activities of the image-creating function in the first variant, it is not possible to identify activities that enable to create (freely) the image. The use of mandatory structures causes an objective presentation of reality, independent of the will of creators of the accounting system in the unit.

Sources of the impact of the image-creating function of accounting can be traced for solutions that provide a check box for the user. The freedom in shaping activities can be considered in the context of assigning to one of the areas of the autogenous presentation of operations, i.e.:

- Creative accounting,

- Aggressive accounting,

- Fraudulent accounting.

P. Gut [2006, s. 10] defines the creative accounting as "keeping registration, records, processing and presentation of economic events with the use of applicable laws and properly interpreted 
accounting rules in a manner that is not directly indicated in these provisions, and which is the result of ingenious, creative and non-standard application of these provisions and rules".

On the other hand, the aggressive accounting, according to A. Wierciński [2008, pp. 147-148] should not be identified (directly) with taking illegal actions. The author expresses the view that the aggressive accounting includes fraudulent activities that do not violate the law.

In such a situation, actions unambiguously inconsistent with applicable legal provisions should be included in the area of fraudulent accounting.

Taking into account the above-mentioned division, it should be stated that the activities undertaken as a part of the implementation of the image-creating function and included in the area of creative accounting will support the obtaining of accurate and reliable information from the accounting system.

Furthermore, activities classified as the fraudulent accounting can be clearly identified as activities contributing to the generation of information that does not indicate fidelity and reliability.

However, such an unambiguous declaration cannot be expressed in the context of the image-creating actions included in the area of the aggressive accounting. The lack of unambiguous legal contraindications suggests that there may be situations that will ultimately generate information with adequate qualitative characteristics.

\section{CONCLUSION}

The aim of this article was to present the impact of the image-creating function of accounting on the quality of information generated by the accounting system.

Accounting has increased the range of functions over the years. Today, in literature, there are many functions realized by accounting, including, among others, the image-creating function, which aims to promote the individual with the use of data contained in the financial statements, while maintaining the superior accounting principle - the principle of accurate and reliable image.

For a wide range of recipients of information coming from the accounting system, its quality (understood through the prism of usefulness and usability) is very important. The desire to realize the image-accounting function may lead to the distortion of financial information. Therefore, it is especially necessary to supervise the observance of the principles of a faithful and reliable image.

\section{REFERENCES}

[1] Brzezin, W., 1998, Ogólna teoria rachunkowości, Wydawnictwo Politechniki Częstochowskiej, Częstochowa.

[2] Cieciura, M., 2016, Rachunkowość jako generator użytecznej informacji ekonomicznej w obliczu dylematu „człowiek racjonalny versus człowiek emocjonalny”, Studia Ekonomiczne. Zeszyty Naukowe UE w Katowicach, nr 300, Katowice.

[3] Kaczmarczyk A., Użyteczność a wiarygodność informacji sprawozdawczej - kierunki zmian, w: Studia Oeconomica Posnaniensia, 2016, vol. 4, no. 11 
[4] Kurek, H., Zielińska, H., 2000, Informacyjna funkcja rachunkowości, w: Dresler, Z., Prace z zakresu rachunkowości, Zeszyty naukowe nr 553 Akademii Ekonomicznej w Krakowie, Wydawnictwo AE Kraków, Kraków, s. 139-149.

[5] Jastrzębowski, A., 2015, Zakres i znaczenie współcześnie identyfikowanych funkcji rachunkowości, http://www.wbc.poznan.pl/Content/351937/Jastrzebowski_Artur_doktorat. pdf.

[6] Messner, Z., 2003, Podstawy rachunkowości, Wydawnictwo Akademii Ekonomicznej im. Karola Adamieckiego w Katowicach, Katowice.

[7] Matuszyk I., Wiarygodność ujawnianych informacji jako podstawa właściwej komunikacji z interesariuszami, w: Finanse, Rynki Finansowe, Ubezpieczenia nr 2/2018 (92)

[8] Nowak, E., 1994, Rachunkowość jako system informacyjny przedsiębiorstwa, w: Nowak, E. (red.), Systemy informacyjno-decyzyjne rachunkowości: materiały na seminarium naukowe zorganizowane przez Instytut Rachunkowości AE Wrocław, Prace Naukowe AE Wrocław nr 690, Wydawnictwo Akademii Ekonomicznej im. Oskara Langego we Wrocławiu, Wrocław, s. 79-82.

[9] Piotrowska K., Wiarygodność sprawozdania zintegrowanego jako źródła informacji o działalności innowacyjnej, w: Studia Oeconomica Posnaniensia, 2016, vol. 4, no. 11

[10] Poetschke, H., 2011, Istota systemu rachunkowości, Gabrusewicz W., Samelak, J. (red.), w: Podstawy Rachunkowości, Wydawnictwo Uniwersytetu Ekonomicznego w Poznaniu, Poznań, s. 11-31.

[11] Rówińska M., Przydatność - podstawowa cecha informacji finansowej?, w: Finanse, Rynki Finansowe, Ubezpieczenia nr 2/2016 (80), cz. 2

[12] Smejda, M., 2011, Teoretyczne aspekty informacyjnego systemu rachunkowości, w: Kostur, A. (red.), Problemy harmonizacji rachunkowości, Wydawnictwo Uniwersytetu Ekonomicznego w Katowicach, Katowice, s. 103-119.

[13] Szychta, A., 1996, Teoria rachunkowości Richarda Mattessicha w świetle podstawowych kierunków rozwoju nauki rachunkowości. Studium metodologiczne, FRR w Polsce, Warszawa. 